\title{
Atlas of the distribution of amphibians and reptiles in the Diawling National Park, Mauritania
}

\author{
Andack Saad Sow ${ }^{1}$, Duarte Vasconcelos Gonçalves ${ }^{2}$, Fábio Vieira Sousa ${ }^{2}$, Fernando Martínez- \\ Freiría ${ }^{2}$, Frederico Santarém²,3, Guillermo Velo-Antón², Hamidou Dieng4, João Carlos Campos², Saer \\ Khayar Diagne ${ }^{5}$, Zbyszek Boratyński², José Carlos Brito ${ }^{2,3, *}$ \\ ${ }^{1}$ Direction du Contrôle Environnemental, Ministère de l'Environnement et du Développement Durable, \\ Nouakchott, R.I. Mauritanie. \\ ${ }^{2}$ CIBIO/InBIO, Centro de Investigação em Biodiversidade e Recursos Genéticos da Universidade do Por- \\ to, Campus Agrário de Vairão, R. Padre Armando Quintas, 4485-661 Vairão, Portugal. \\ ${ }^{3}$ Departamento de Biologia da Faculdade de Ciências da Universidade do Porto. Rua Campo Alegre, 4169- \\ 007 Porto, Portugal. \\ ${ }^{4}$ Faculté des Sciences et Techniques, Université des Sciences, de Technologie et de Médecine de Nouak- \\ chott, B.P. 5026 Nouakchott, R.I. Mauritanie. \\ ${ }^{5}$ Parc National du Diawling, B.P. 3935 Nouakchott, R.I. Mauritanie.
}

*Correspondence: Phone: +351 252660416, Fax: +351 252661780, E-mail: jcbrito@cibio.up.pt

Received: 14 August 2017; returned for review: 25 October 2017; accepted 26 October 2017.

This study provides the first atlas of the distribution of amphibians and reptiles in the Diawling National Park (DNP), Mauritania. Unpublished fieldwork observations collected between 2010 and 2017 were combined with published records and museum data in a geographical information system to produce maps with the distribution of individual species and species richness. The taxonomic list includes 32 species, six amphibians and 26 reptiles, grouped in 17 families. Ten species are new records for the area. Species form distinct groups according to their distribution patterns and preliminary habitat selection trends: 1) species distributed in inland dunes, some extending their range to coastal dunes; 2) species distributed in inland dunes and floodplains; and 3) species associated with habitats that are permanently or seasonally flooded or that inhabit riparian forests. Three areas accumulating most of the species found are located in sand habitats of DNP and peripheral zones. Specific counts of Crocodylus suchus suggest strong seasonal fluctuations in population size inside DNP, which are likely a consequence of the human-mediated dynamics of water availability in the area.

Key words: Africa; biodiversity; GIS; protected area; wetlands.

West Africa contains various ecosystems, ranging from dry savannah to tropical forest, that are home to more than 2000 amphibian, bird and mammal species (MALlon et al., 2015). The globally significant biodiversity levels in the region have long been recognized, and protected areas have been established to preserve such biodi- versity. In particular, wetland environments in coastal areas have been targeted for biodiversity conservation due to their outstanding importance to migratory birds (RAMPAO, 2015).

In Mauritania, the Diawling National Park (DNP) is an area of global importance for its diversity of water-birds, accumulat- 
ing almost 250000 individuals during winter (Shine et al., 2001; PN Diawling, 2017). The area is a costal floodplain on very saline clay and silt with low sand relief in the lower delta of the Senegal River (Fig. 1). The DNP was created in 1991 by Mauritanian authorities as a response to the socio-economic and environmental degradations generated by the construction of the Diama dam in 1986, downstream of the river (BARRY \& TAїBI, 2011). The dam was built to block intrusion of salty water from the Atlantic Ocean, to facilitate perennial irrigation, and to improve water supply, but it altered the estuary hydrodynamics and two thirds of the park are now deprived from direct freshwater supply from the Senegal River (Diarra, 1994; BA et al., 2002). Consequently, the increased salinity levels in the floodplain caused the collapse of fishery resources and bird colonies, estuarine vegetation virtually disappeared, and the mangrove (Avicennia germinans and Rhizophora racemosa) was reduced to less than $10 \%$ of its 1960 extent (IUCN, 1989; BA et al., 2002). At the same time, increased availability of freshwater in the main course of the Senegal River boosted the development of invasive vegetation (Typha sp.; IUCN, 2007). In 1994, the DNP and the western peripheral zone (Fig. 1) were categorised as Ramsar Wetland (DiARRA, 1994), which together with the Senegalese part of the delta, were declared as Transboundary Biosphere Reserve (TBR) of the Senegal River Delta in 2005. Restoring ecosystems and floodplain hydrodynamics have been subject of intense research and management, and, as from 1994, management of flood releases were used to par- tially rehabilitate the floodplain and to create an artificial estuary (HAMERLYNCK \& Cazottes, 1998; Hamerlynck et al., 1999, 2005; Ba et al., 2002; Duvail \& HamerLyNCK, 2003; Degeorges \& Reilly, 2006; BARRY \& TAÏBI, 2011). The simulation of the pre-dam hydrodynamics partially allowed restoring ecosystem functions, with positive impacts on biodiversity and traditional human activities (HAMERLYNCK et al., 2005; Hamerlynck \& Duvail, 2009; Ly \& ZEIN, 2009).

Contrarily to birds and mammals, knowledge on the amphibian and reptile species of DNP is very limited. Until the late 1980s, 11 amphibians or reptiles were known broadly from south-western Mauritania (LE BERRE, 1989). This number was increased to 19 species with the inventories made during the project Biodiversité du Littoral Mauritanien, which included two localities close to DNP (Arvy \& TIJANE, 1997; INEICH, 1997). Posterior works targeting the distribution of amphibians and reptiles at country-level (BRITO, 2003; Nickel, 2003; Padial, 2006; Brito et al., 2008) or of particular species (CROCHET et al., 2003; PAdial, 2003; Brito et al., 2012; VALE et al., 2014) have set the taxonomic list of DNP in two amphibians and 20 reptiles. However, data on species distribution at local scale and on areas concentrating most species are largely unavailable, which hampers conservation planning of biodiversity. Furthermore, there is evidence of regional ecosystem changes through time (initial degradation followed by restoration) modifying population dynamics of, at least, aquatic reptiles. For instance, West-African crocodiles (Crocodylus suchus) were regionally abun- 
dant, but after the closure of Diama dam in 1986 they were considered as locally extinct (IUCN, 1989; HAMERLYNCK et al., 1999). In 2010, the species was rediscovered in the area (BRITo et al., 2012), but quantitative data on population size or trends are lacking.

The major aims of this work are: 1) to provide an updated taxonomic list of the amphibians and reptiles present in the DNP; 2) to map their distributions; and 3) to identify areas concentrating species richness. In addition, the study aims at providing preliminary data on local population size and trends of crocodiles. The present work, together with the inventories made in the Banc d'Arguin National Park (Sow et al., 2014a,b), fulfil a previous knowledge gap in the distribution of amphibians and reptiles in protected areas of coastal Mauritania.

\section{Materials and Methods}

\section{Study area}

The study area (latitudes $16^{\circ} 02.39^{\prime}$ to $16^{\circ} 36.40^{\prime} \mathrm{N}$ and longitudes $16^{\circ} 14.30^{\prime}$ to $16^{\circ}$ $\left.31.10^{\prime} \mathrm{W}\right)$ covers the DPN $\left(200 \mathrm{~km}^{2}\right)$ and the peripheral costal area $\left(546 \mathrm{~km}^{2}\right)$, and it is located along the coastal Atlantic region of southern Mauritania, West Africa (Fig. 1 ). The area is mostly flat (maximum altitude $9 \mathrm{~m}$ ) and climate is arid and hot, with minimum and maximum annual precipitation and annual average temperature ranging between 168 and $276 \mathrm{~mm}$ and 24.7 and $26.3{ }^{\circ} \mathrm{C}$, respectively (Hijmans et al., 2005). About $73 \%$ of the study area is covered by multiple water / wetland habitat types and the terrestrial habitats $(27 \%$ of the area) include coastal dunes, inland dunes, and inland islands. Coastal dunes $\left(36.7 \mathrm{~km}^{2} ; 5 \%\right.$ of the area) are typically composed of loose white sand and are covered by sparse grasslands and shrublands, while inland dunes $\left(156.7 \mathrm{~km}^{2} ; 21 \%\right)$ are typically composed of compact yellow sand and are covered by sparse Acacia trees (A. tortilis, A. senegal), Euphorbia balsamifera, and Balanites aegyptiaca (the latter two especially in coastal areas, where they forms woodlands), with a herbaceous cover of Cenchrus biflorus, Chloris prieurii and Schoenefeldia gracilis (SHINe et al., 2001). There are several small islands in the extreme southern areas $\left(7.8 \mathrm{~km}^{2} ; 1 \%\right)$ surrounded by brackish water, where relict mangrove stands are found, which testify past humid conditions in the region (GAsse, 2000).

\section{Fieldwork and data analysis}

Fieldwork was performed during a total of 26 days, distributed in eight visits between 2010 and 2017 (Fig. 1). Sampling sites were selected in order to cover the environmental variability of terrestrial habitats of the study area, as well as particular topographic features, such as the Chott Boul wetland. Visual encounter surveys by foot were performed on average by 3.8 persons (range 3 to 6 persons) for no longer than 1 hour (sampling effort ranging from 0.02 to 1.01 persons / hour / day). Night sampling was performed opportunistically around camping sites. Ad hoc observations (road-kills and live specimens) collected by the authors and National Park staff were also recorded. Captured specimens were photographed, a tissue sample was collected, and the geographic coordinates of the locality were recorded with a global positioning system (GPS). 


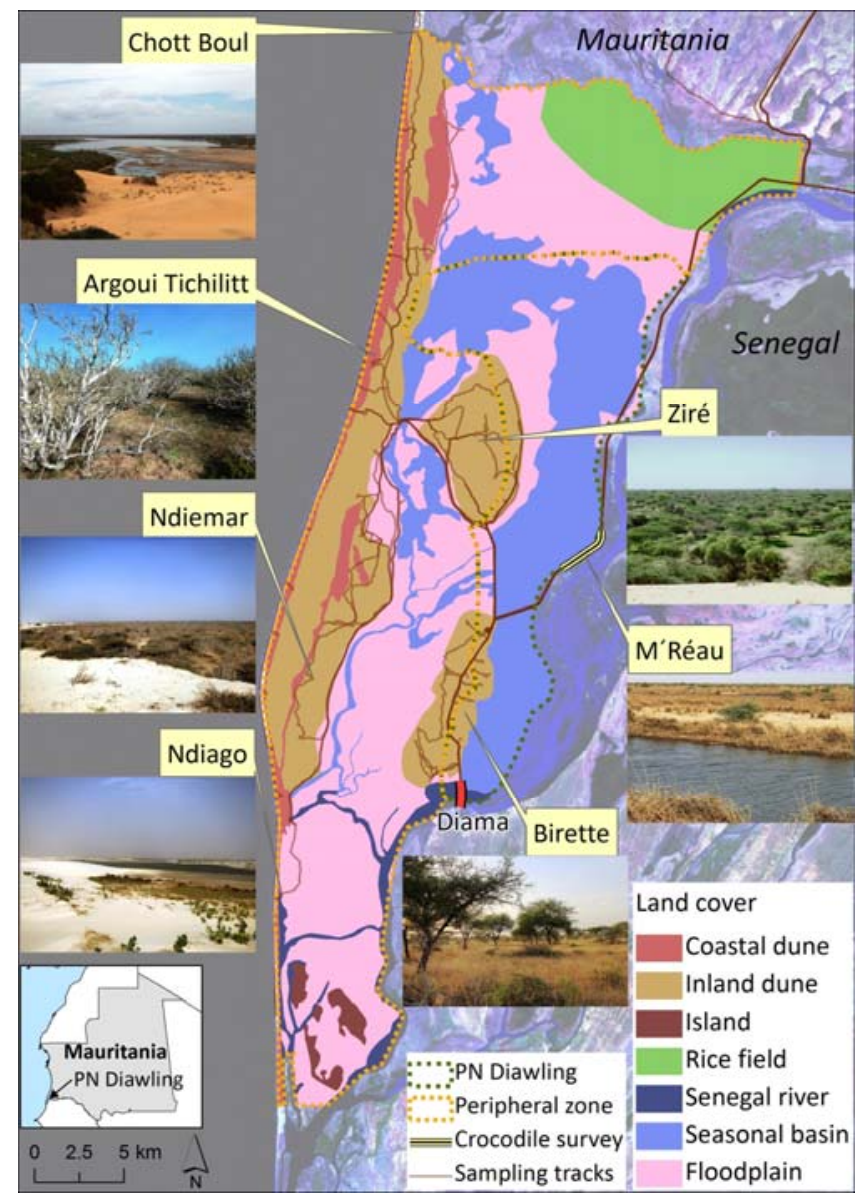

Figure 1: Limits of the Diawling National Park and the peripheral zone, tracks of sampling routes (between 2010-2017), land-cover categories, and localities mentioned in text. For a correct visualization of the figure, readers are referred to the online, coloured version.

A georeferenced database of fieldwork observations was created and complemented with published data (ARvy \& TIJANE, 1997; INEICH, 1997; BRITO, 2003; CROCHET et al., 2003; Nickel, 2003; PAdial, 2003, 2006; BRITO et al., 2008, 2012; VALE et al., 2014; ObServation International, 2017). Geographic coordinates of bibliographic references were collected from topographical maps of Mauritania (Institut Géographique National; scale 1:200 000). Specimens from the study area available at the collection of the Muséum national d'Histoire naturelle of Paris (INEICH, 1997) were also included in the database.
The distributions of individual species and species richness were projected on the coordinate system WGS 1984 UTM Zone $28 \mathrm{~N}$, using the geographical information system ArcGIS 10.0 (ESRI, Redlands, California, USA). Species maps represent fieldwork and published observations over $2 \mathrm{x}$ $2 \mathrm{~km}$ UTM grid cells (232 cells in total) and the species richness map represents number of species observed over $5 \times 5 \mathrm{~km}$ UTM grid cells (51 cells in total). Observations of species with more than eight recorded localities were intersected with land-cover categories, extracted from Google Earth, to quantify preliminary patterns of habitat 
Herpetofauna of DiaWling NATIONAL Park, MAURitania

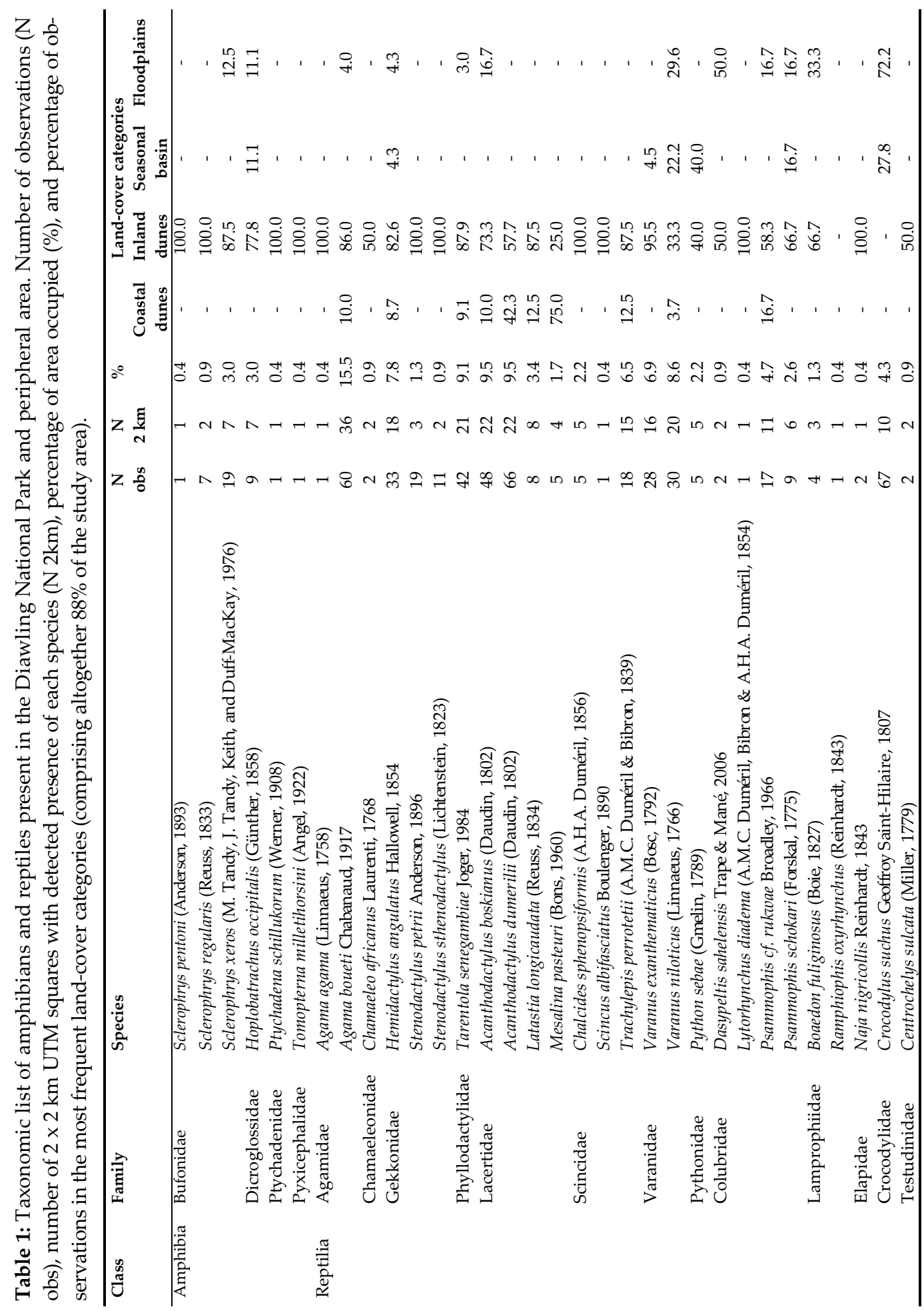


selection.

One transect of $3163 \mathrm{~m}$ of length in the M'Réau area (Fig. 1) was established specifically for counting C. suchus. Surveys were made from the international road delimiting the eastern border of the study area. Surveys were made only to the western side of the road, dominated by a seasonal basin with sparse vegetation cover, because the eastern side corresponds to the main Senegal river and is fully covered by the invasive Typha sp.. Surveys were performed in November 2012, November 2014, August 2015, January 2016, and April 2017. All surveys were standardised and followed baseline methodology for crocodile counting previously used in Mauritania (BRITo et al., 2011; CAMpos et al., 2016): an observer installed over the rooftop of a four-wheel drive vehicle moving along the transect line, holding a highpower lamp, counted the number of pairs of eyes (from yellowish to goldish) that reflected the light emitted by the lamp within a distance of up to $100 \mathrm{~m}$. Surveys started at around 23:00 $\mathrm{h}$ and lasted about $15 \mathrm{~min}$ (average vehicle speed $12.7 \mathrm{~km} / \mathrm{h}$ ), which allows the direct comparison of the total number of crocodiles observed in each survey.

\section{Results}

The published and fieldwork data comprised 525 records (487 unpublished observations and 38 published observations) from six amphibian and 26 reptile species, grouped in four and 13 families, respectively (Table 1). Detailed distributions are presented in Figs. 2-7. In relation to the previously published data, 10 new species were detected in the study area: 1) four amphibians, i.e. Hoplobatrachus occipitalis, Ptychadena schillukorum, Sclerophrys xeros, and Tomopterna milletihorsini (Fig. 2); 2) three reptiles mostly associated with inland dunes of Birrete, i.e. Agama agama, Boaedon fuliginosus, and Naja nigricollis (Figs. 3 and 5); and 3) three reptiles associated with coastal dunes, i.e. Lytorhynchus diadema, Mesalina pasteuri, and Scincus albifasciatus (Figs. 4-6). On the contrary, the snakes Dasypeltis sahelensis and Ramphiophis oxyrhynchus, and the turtle Centrochelys sulcata that were known from less than two localities in the area (Arvy \& TiJAne, 1997) were not observed during our field surveys.

General patterns of habitat selection were observed among the amphibians and reptiles in the study area (Table 1): 1) species mostly related to the coastal and inland dunes (Birrete and Ziré), such as $A g a$ ma boueti, Hemidactylus angulatus, Tarentola senegambiae, Trachylepis perrotetii, and Varanus exanthematicus, or restricted to the coastal dunes, such as Acanthodactylus dumerilii, Latastia longicaudata, and M. pasteuri; 2) species mostly related to inland dunes and floodplains, such as Acanthodactylus boskianus, $H$. occipitalis, and S. xeros; and 3) species associated with habitats that are permanently or seasonally flooded, such as C. suchus, Python sebae, and Varanus niloticus, or that inhabit the riparian forests, such as Psammophis cf. rukwae (following KelLy et al., 2008).

The distribution of observed species richness exhibits spatial asymmetries, and three areas accumulating more than 10 species can be identified: 1) the area south of Chott Boul; 2) Ziré and Argoui Tichilitt dunes; and 3) Birette dune, especially its north-eastern area (Fig. 8). These areas are 

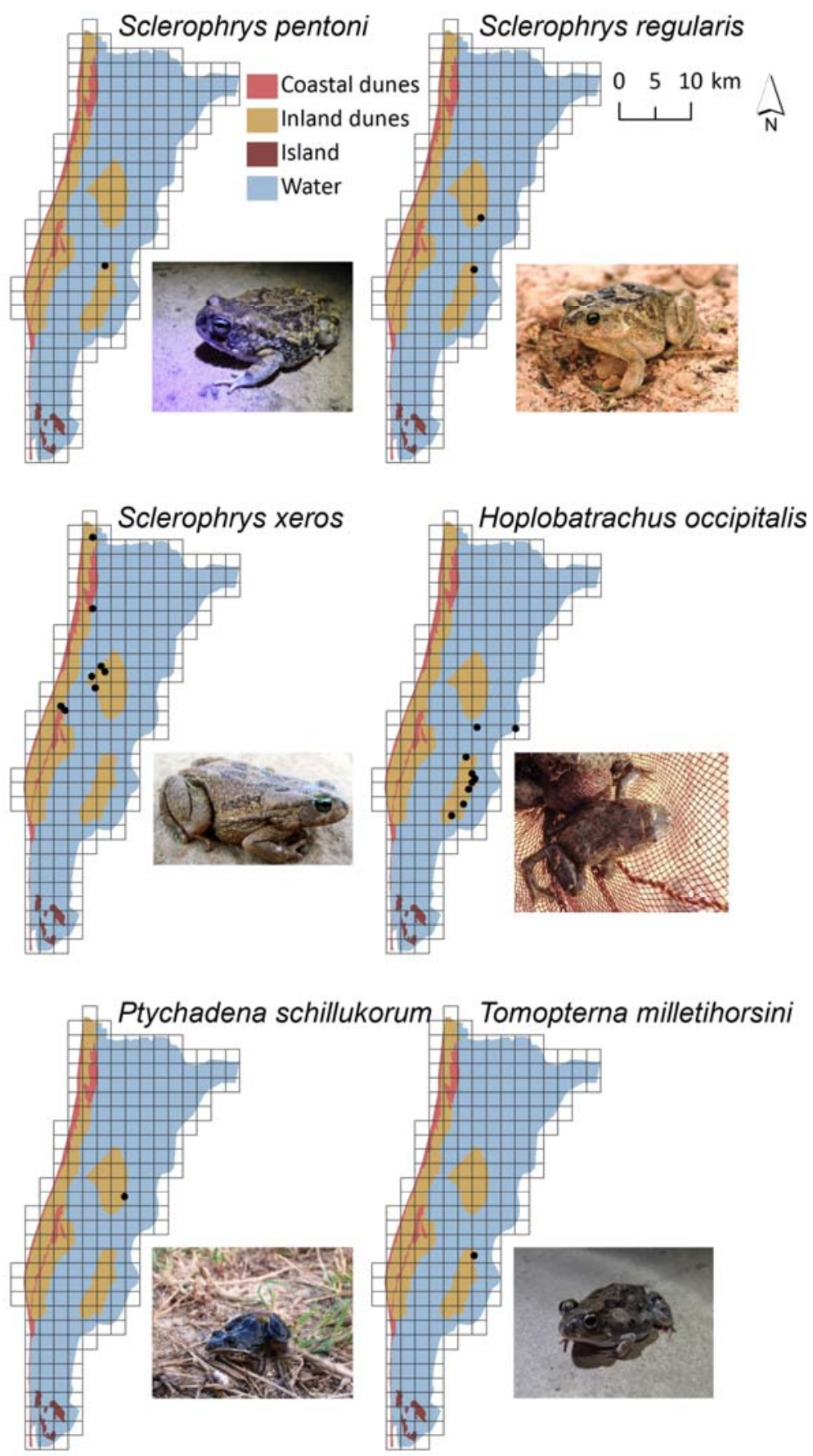

Figure 2: Distribution of Sclerophrys pentoni, S. regularis, S. xeros (specimen from Assaba region), Hoplobatrachus occipitalis, Ptychadena schillukorum, Tomopterna milletihorsini, and non-flooded landcover categories in the Diawling National Park and the peripheral zone at a $2 \times 2 \mathrm{~km}$ UTM scale. 

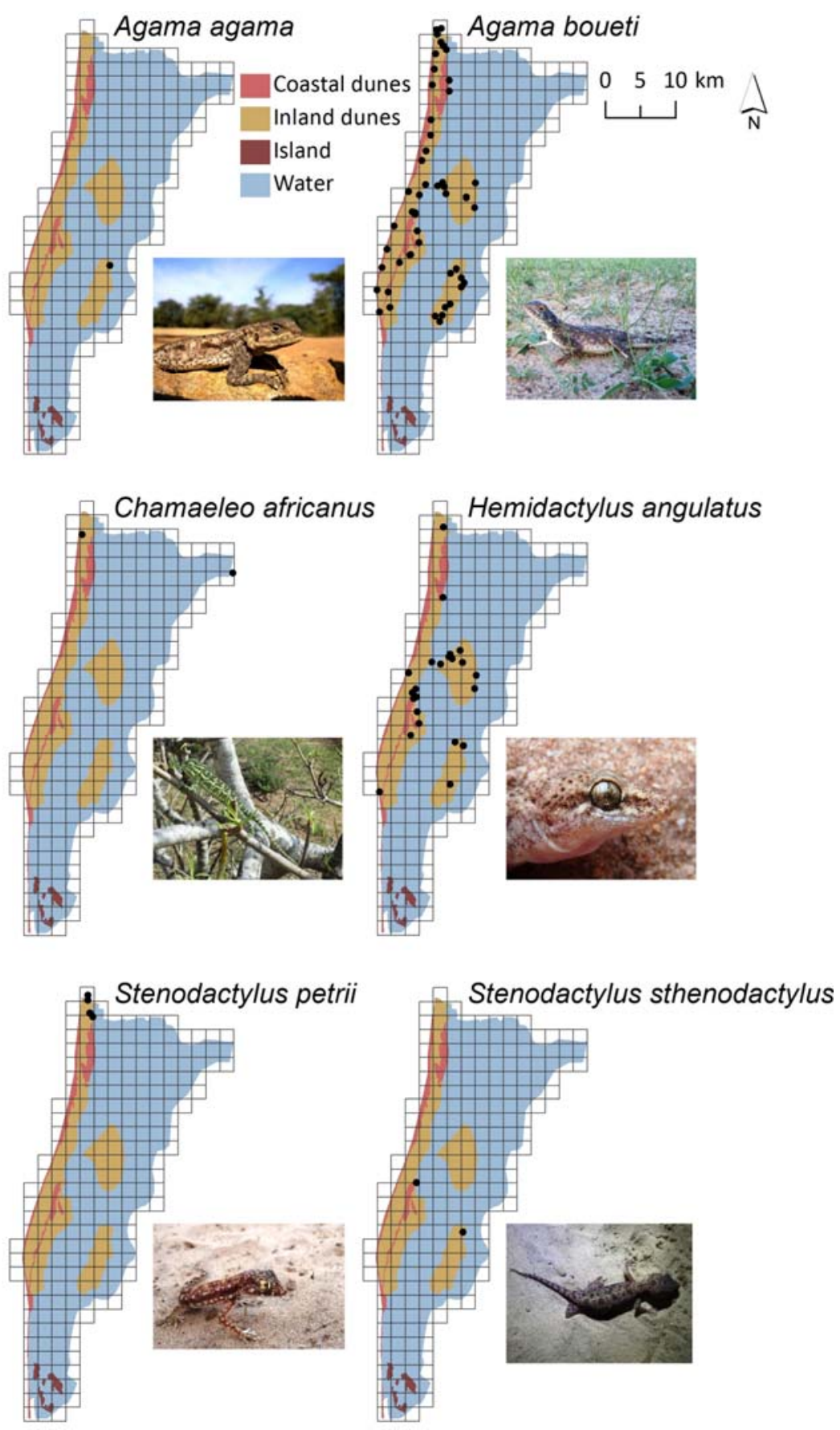

Figure 3: Distribution of Agama agama, A. boueti, Chamaeleo africanus, Hemidactylus angulatus, Stenodactylus petrii, S. sthenodactylus, and non-flooded land-cover categories in the Diawling National Park and the peripheral zone at a $2 \times 2 \mathrm{~km}$ UTM scale. 

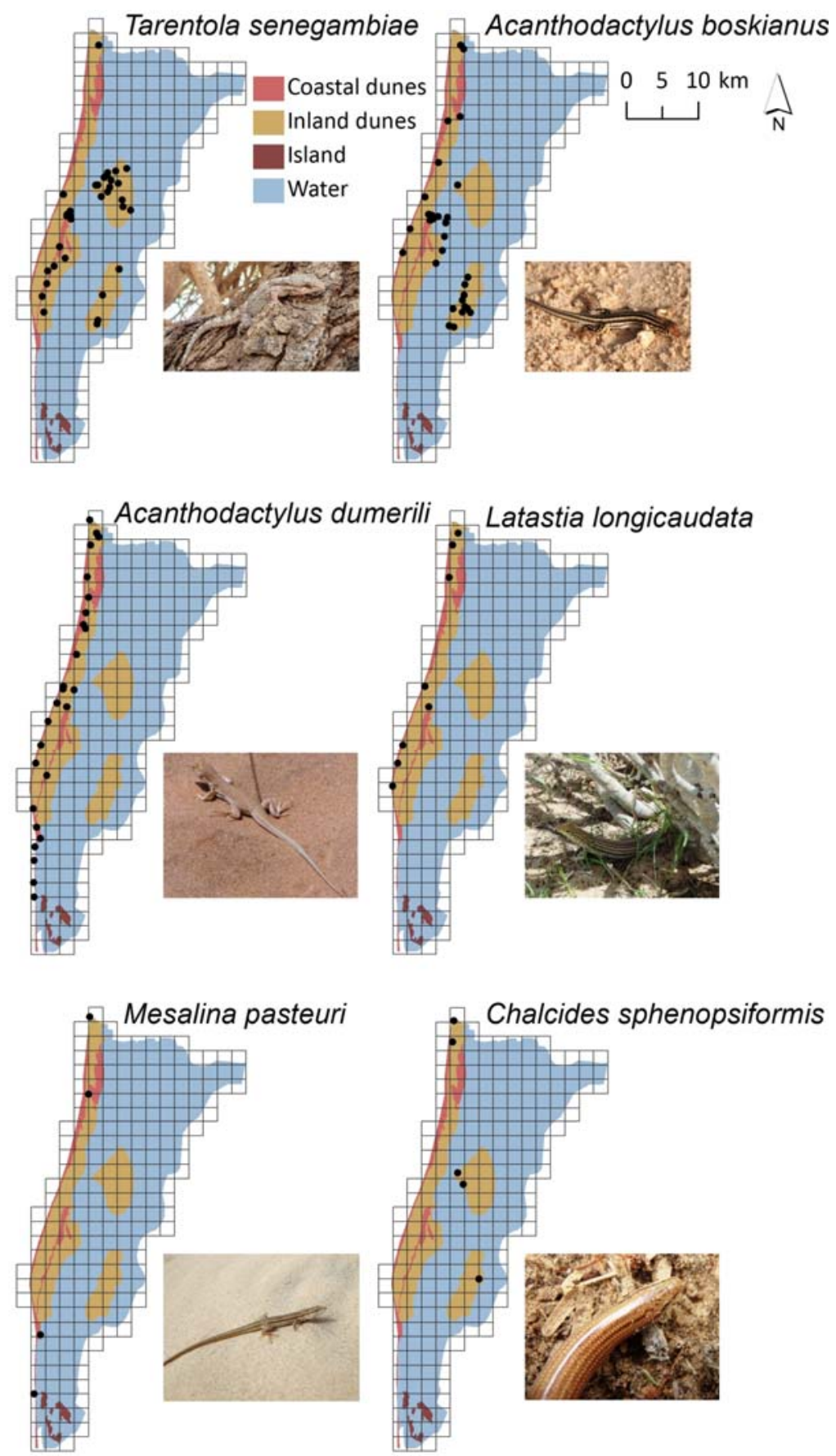

Figure 4: Distribution of Tarentola senegambiae, Acanthodactylus boskianus, A. dumerili, Latastia longicaudata, Mesalina pasteuri, Chalcides sphenopsiformis, and non-flooded land-cover categories in the Diawling National Park and the peripheral zone at a $2 \times 2 \mathrm{~km}$ UTM scale. 

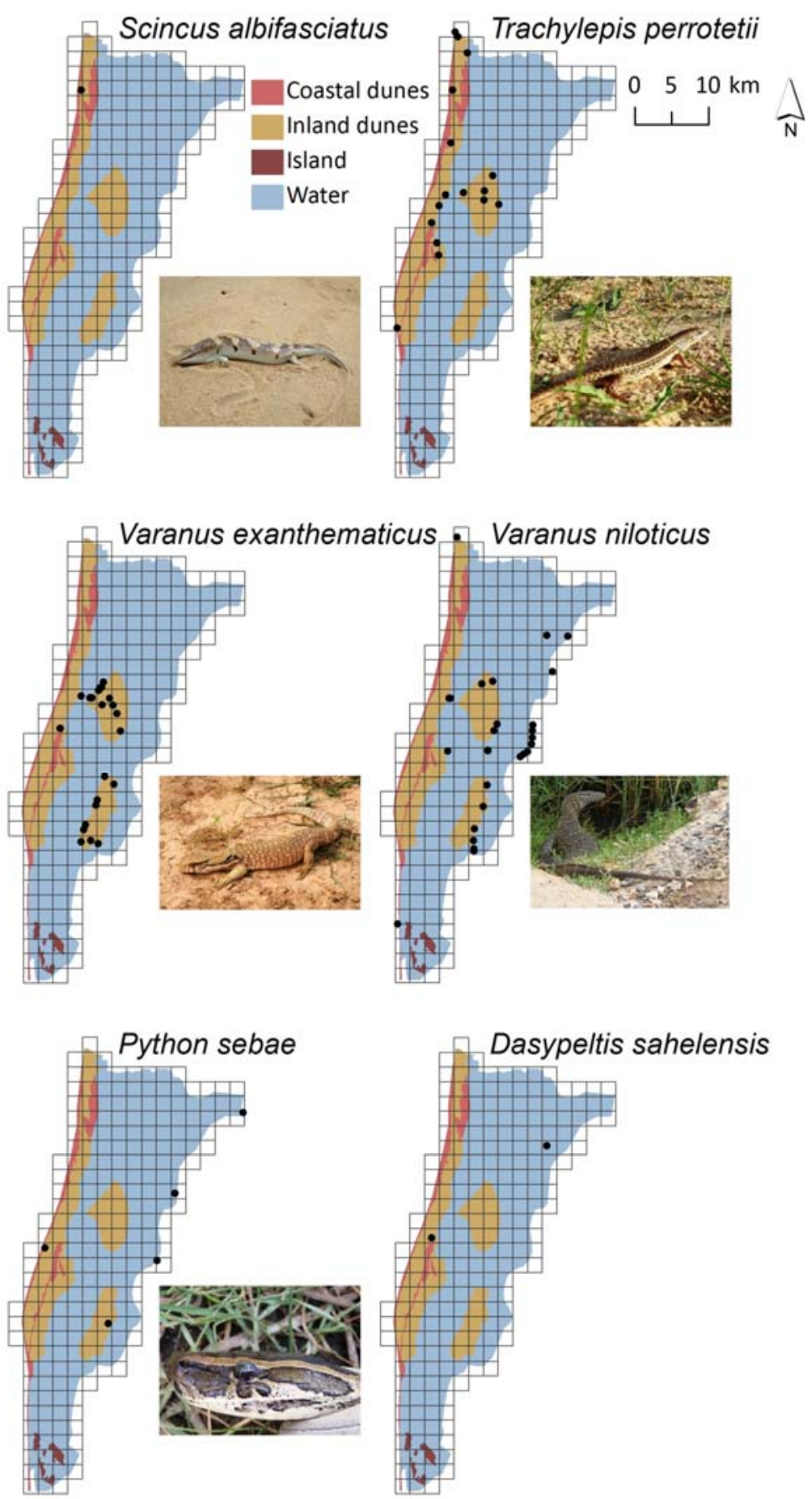

Figure 5: Distribution of Scincus albifasciatus, Trachylepis perrotetii, Varanus exanthematicus, $V$. niloticus, Python sebae, Dasypeltis sahelensis (no picture available), and non-flooded land-cover categories in the Diawling National Park and the peripheral zone at a $2 \times 2 \mathrm{~km}$ UTM scale. 

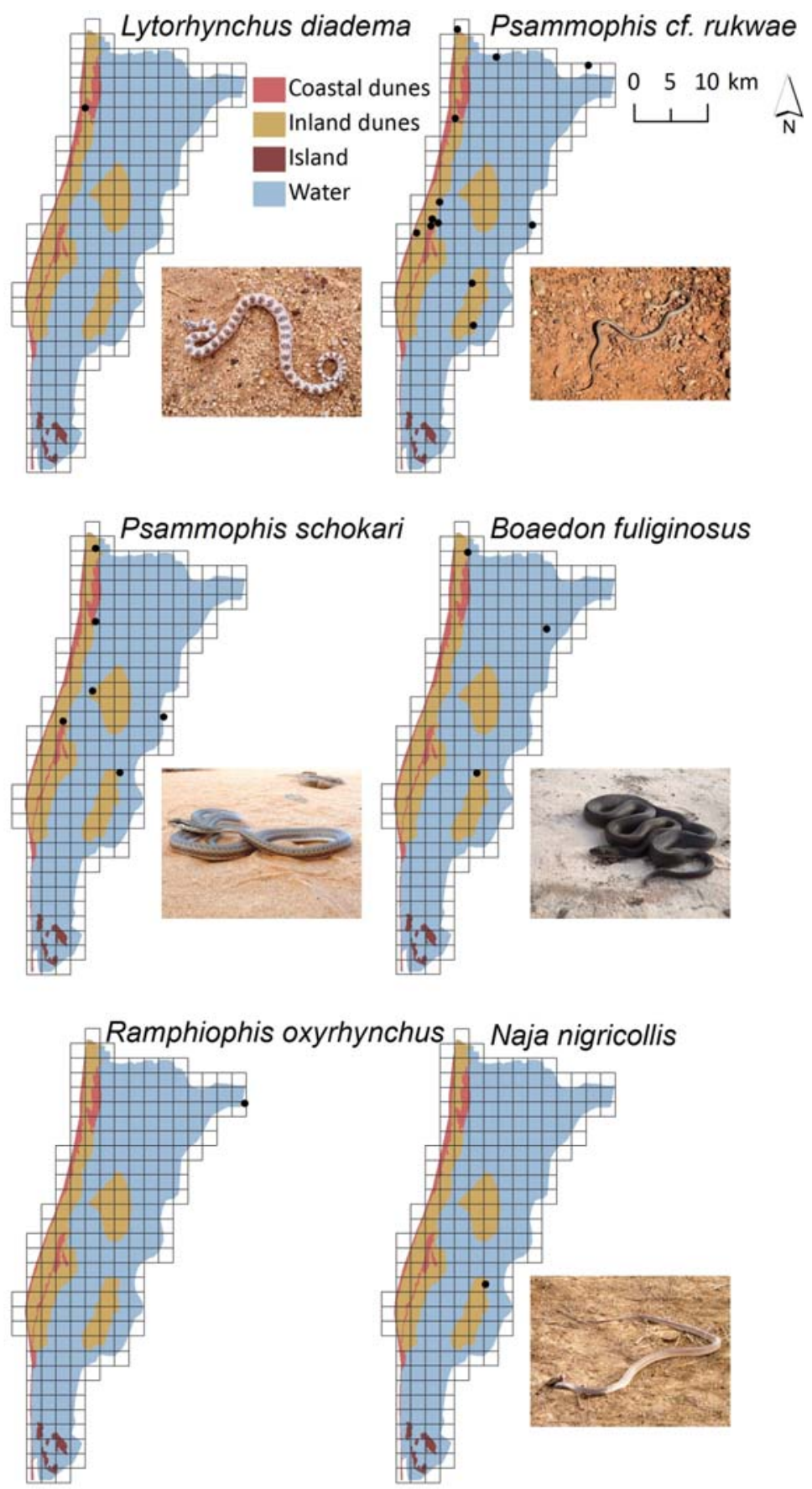

Figure 6: Distribution of Lytorhynchus diadema (specimen from Dakhlet-Nouadhibou region), Psammophis cf. rukwae (specimen from Gorgol region), P. schokari (specimen from Adrar region), Boaedon fuliginosus, Ramphiophis oxyrhynchus (no picture available), Naja nigricollis, and non-flooded landcover categories in the Diawling National Park and the peripheral zone at a $2 \times 2 \mathrm{~km}$ UTM scale. 


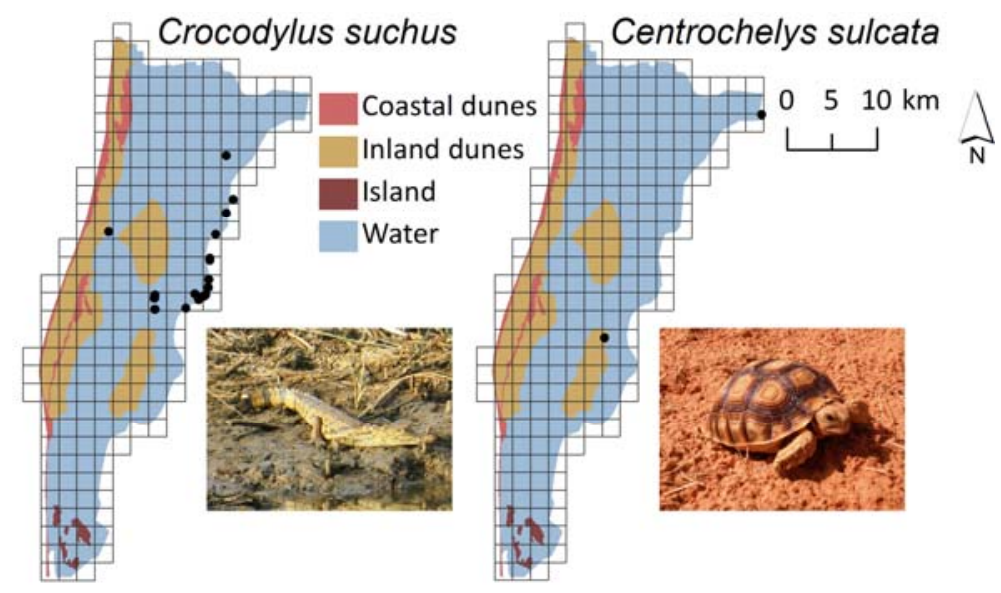

Figure 7: Distribution of Crocodylus suchus, Centrochelys sulcata (specimen from Hodh El Gharbi region), and non-flooded land-cover categories in the Diawling National Park and the peripheral zone at a $2 \times 2 \mathrm{~km}$ UTM scale.

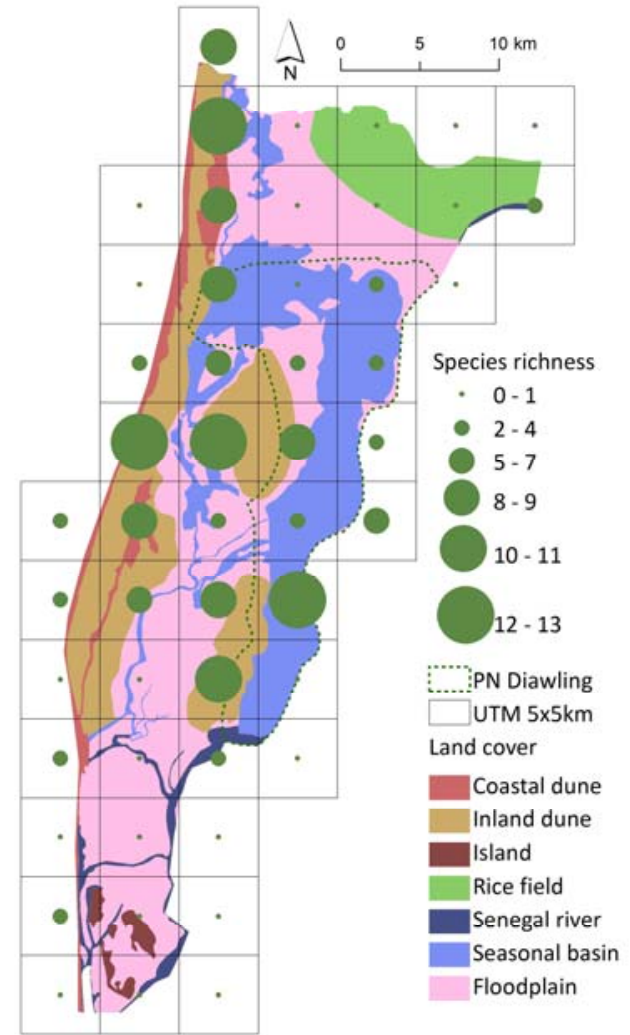

Figure 8: Distribution of amphibian and reptile species richness and land-cover categories in the Diawling National Park and the peripheral zone at a $5 \times 5 \mathrm{~km}$ UTM scale. For a correct visualization of the figure, readers are referred to the online, coloured version. located in the transition zones from seasonally flooded land-cover categories to coastal / inland dunes, and thus accumulate species that are mostly found in each of the land-cover categories. For example, the Ziré-Argoui Tichilitt dunes gather species typical of costal dunes (A.dumerilii, $L$. longicaudata), of inland dunes ( $S$. xeros, $V$. exanthematicus), or of both types of dunes ( $A$. boueti, Chalcides sphenopsiformis, $H$. angulatus, Psammophis schokari, T. senegambiae, T. perrotetii), and flooded habitats (C. suchus, V. niloticus).

The numbers of crocodiles observed (including juveniles and adults) were: 38 individuals in 2012, 68 individuals in 2014, two individuals in 2015, 40 individuals in 2016, and 47 individuals in 2017.

\section{Discussion}

Ten new species were detected for the first time in the study area. These include the amphibians $P$. schillukorum, that was recently described for Mauritania (SÁnchezVialas et al., 2017), and T. milletihorsini, which replaces the former designation of $T$. cryptotis given to West-African populations (OHLer \& Frétey, 2008; ZimkUs \& LARson, 
2011). Our observations of L. diadema and M. pasteuri along coastal dunes expand their known range southwards and constitute the extreme south-western limits of their ranges (Trape \& Mané, 2006; Trape et al., 2012). On the contrary, the turtle C. sulcata and the snakes D. sahelensis and R. oxyrhynchus, that had been previously reported for the study area (Arvy \& TiJANE, 1997; INEICH, 1997; NiCKEL, 2003), were not detected, which might be related to seasonal activity cycles, low detectability and / or low abundance. Furthermore, the snakes Malpolon moilensis and Bitis arietans were not observed but are known from surrounding areas to the north and to the south, respectively, of the study area (TRAPE \& MANé, 2006). Further sampling is needed to determine the potential presence of these taxa in the region.

Nine species, including three amphibians and six reptiles, were observed in less than two localities. The low detectability of Chamaeleo africanus, L. diadema, and $S$. albifasciatus may have hampered the additional detection of these species along inland / coastal dunes. On the contrary, the amphibians P. schillukorum, Sclerophrys pentoni, and T. milletihorsini may be locally rare due to the salinity levels of most floodplains. Further sampling is needed to understand if they are locally rare, exhibit low detectability, and / or were not recorded because sampling occurred during periods of low activity.

The richest areas in amphibians and reptiles were observed in sand habitats of DNP and its peripheral zone. Such observation stresses the importance of the peripheral zone of this relatively small national park for local biodiversity conserva- tion, as observed in other areas (e.g. LujA et al., 2017). The peripheral zone is included in the Ramsar Wetland and in the Transboundary Biosphere Reserve (TBR) of the Senegal River Delta, which should contribute to framing local biodiversity conservation planning.

While the absolute number of crocodiles observed in M'Réau transect increased from a few individuals recorded in 2010 up to a maximum of 68 individuals, the most striking pattern was the extreme fluctuation in crocodile counts (decreasing from 68 individuals in autumn 2014 to just two individuals in summer 2015). These extreme fluctuations are probably associated with the dynamics of water availability in the DNP; after the controlled flooding of the basins (after mid-August), the number of observed crocodiles was the highest recorded. In winter, when water levels start to decrease, there were fewer observations (40 and 47 individuals in January and April, respectively). During the dry season, the floodplain is mostly dry and crocodiles are forced to find shelter (digging caves in the muddy river banks) and / or to move to the adjacent Senegal River watercourse. There have been occasional observations by local fishermen of crocodiles crossing the dam that runs alongside the park to reach the Senegal River. The road built over this dam has a considerable amount of vehicle traffic (it is presently the single overland access to Senegal). In the M'Réau sector of the dam, one adult crocodile was found road-killed, besides two $P$. sebae and four $V$. niloticus. There is a project to asphalt the current road, which will have negative ecological and tourist impacts, since the dike is the 
best site for bird watching (IUCN, 2007). In 2017, DNP installed warning signs in the M'Réau sector about the presence of crocodiles and the sensitivity of the region to road traffic. The construction of an international large bridge between Mauritania and Senegal in Rosso (about $50 \mathrm{~km}$ to the east of DNP) would help minimising the negative impacts of local traffic in the Park and its biodiversity.

\section{Acknowledgement}

Fieldwork was partially supported by RAMPAO (Appui à la réalisation d'un atlas des reptiles et amphibiens sur le Parc National du Diawling et sa périphérie), National Geographic Society (8412-08), Mohammed bin Zayed Species Conservation Fund (11052709, 11052707, 13257467), Ruffords Small Grant (17893-1), Fundação para a Ciência e Tecnologia (FCT: PTDC/ BIA-BEC/099934/2008, PTDC/BIABIC/2903/2012), and by FEDER through COMPETE-Operational Programme for Competitiveness Factors (FCOMP-01-0124FEDER-008917, -028276). FMF, FS, GVA, $\mathrm{ZB}$ and JCB are supported by FCT (SFRH/ BPD/109119/2015, PD/BD/132407/2017, IF/01425/2014， SFRH/BPD/84822/2012, IF/00459/2013, respectively). Logistic support for fieldwork was given by D.O.S. Ould Daf, A. Magrega, B. Melis, M. Serbera, M. Aveloitt, M.L. Ould Cherif, and Z.E.A. Ould Sidaty (PN Diawling), A. Araújo (MAVA Foundation), Pedro Santos Lda. (Trimble GPS), and Off Road Power Shop. J. Marques, H. Rebelo, P. Sierra and N. Sillero helped in the fieldwork.

\section{REFERENCES}

Arvy, C. \& Tijane, D.A. (1997). Données sur les tortues marines et sur la tortue terrestre du littoral mauritanien, In Colas (ed.) Environnement et Littoral Mauritanien. Actes du Colloque, 12-13 Juin 1995, Nouakchott, Mauritanie. CIRAD, Montpellier, France, pp. 101-104.

Ba, A.; Fall, O. \& Hamerlynck, O. (2002). Le Parc National du Diawling: expérience de cogestion pour la restauration des plaines inondables, In M. Gawler (ed.) Strategies for Wise Use of Wetlands: Best Practices in Participatory Management. Series: Wetlands International Global Series, vol. 8. Wetlands International IUCN - WWF - Ministry of Science and Environmental Protection of Senegal, Wageningen, The Netherlands, pp. 19-25.

Barry, M.H. \& Taïbi, A.N. (2011). Du Parc National du Diawling à la Réserve de Biosphère Transfrontalière: jeux d'échelles à l'épreuve du développement durable dans le bas delta du fleuve Sénégal, In Bart, F. (coord.) Natures Tropicales: Enjeux Actuels et Perspectives. Presses Universitaires de Bordeaux, Bordeaux, France, pp. 147-156.

Brito, J.C. (2003). Observations of amphibians and reptiles from North and West Africa Morocco, Mauritania and Senegal. Boletín de la Asociación Herpetológica Española 14: 2-6.

Brito, J.C.; Campos, J.C.; Gonçalves, D.V.; Martínez-Freiría, F.; Sillero, N.; BoraTYŃSKI, Z. \& Sow, A.S. (2012). Status of Nile crocodiles in the lower Senegal River basin. Crocodile Specialist Group Newsletter 30: 7-10.

Brito, J.C.; Martínez-Freiría, F.; Sierra, P.; Sillerro, N. \& Tarroso, P. (2011). Crocodiles in the Sahara Desert: an update of distribution, habitats and population status for conservation planning in Mauritania. PLoS One 6: e14734.

Brito, J.C.; Rebelo, H.; Crochet, P.-A. \& GeNIEZ, P. (2008). Data on the distribution of amphibians and reptiles from North and West Africa, with emphasis on Acanthodactylus lizards and the Sahara Desert. The Herpetological Bulletin 105: 19-27.

Campos, J.C.; Martínez-Freiría, F.; Sousa, F.V.; Santarém, F. \& BRito, J.C. (2016). Update of distribution, habitats, population size, and 
threat factors for the West African Crocodile in Mauritania. Amphibia-Reptilia 37: 325-330.

Crochet, P.-A.; Geniez, P. \& Ineich, I. (2003). A multivariate analysis of the fringe-toed lizards of the Acanthodactylus scutellatus group (Squamata: Lacertidae): systematics and biogeographical implications. Zoological Journal of the Linnean Society 137: 117-155.

Degeorges, A. \& Reilly, B.K. (2006). Dams and large scale irrigation on the Senegal River: impacts on man and the environment. International Journal of Environmental Studies 63: 633-644.

Diarra, M. (1994). Fiche descriptive sur les zones humides Ramsar. Parc National du Diawling. Wetlands International, Wageningen, The Netherlands. Available at https:// rsis.ramsar.org/RISapp/files/RISrep/

MR666RIS.pdf. Retrieved on 15 November 2017.

Duvail, S. \& Hamerlynck, O. (2003). Mitigation of negative ecological and socio-economic impacts of the Diama dam on the Senegal River Delta wetland (Mauritania), using a model based decision support system. Hydrology and Earth System Sciences 7: 133-146.

Gasse, F. (2000). Hydrological changes in the African tropics since the Last Glacial Maximum. Quaternary Science Reviews 19: 189211.

Hamerlynck, O. \& Cazottes, F. (1998). Le Parc National du Diawling (Mauritanie): infrastructures hydrauliques pour la restauration d'une plaine d'inondation et la création d'un estuaire artificiel. Sud Sciences $\mathcal{E}$ Technologies 1: 28-38.

Hamerlynck, O. \& Duvail, S. (2009). Mission d'Appui à l'Elaboration d'un Plan de Gestion de la Réserve de Biosphère Transfrontalière du BasDelta Mauritanien et de son Aire Centrale le Parc National du Diawling - partim Étude Hydroécologique. R.I. Mauritanie, Ministère Délégué Chargé de l'Environnement et du Développement Durable, Parc National du Diawling, Nouakchott, Mauritania.
Hamerlynck, O.; Duvail, S.; Messaoud, B.O. \& Benmergui, M. (2005). The restoration of the lower delta of the Senegal River, Mauritania (1993-2004), In J.J. Symoens (ed.) Coastal Ecosystems of West Africa, Biological DiversityResources-Conservation. Foundation for the Promotion of Scientific Research in Africa, Brussels, Belgium, pp. 195-210.

Hamerlynck, O.; BabA, M.L.O \& Duvail, S. (1999). The Diawling National Park: Joint management for the rehabilitation of a degraded coastal wetland. Vida Silvestre Neotropical 7: 59-70.

Hijmans, R.J.; Cameron, S.E.; Parra, J.L.; Jones, P.G. \& JARvis, A. (2005). Very high resolution interpolated climate surfaces for global land areas. International Journal of Climatology 25: 1965-1978.

INEICH, I. (1997). Les amphibiens et les reptiles du littoral mauritanien, In Colas (ed.) Environnement et Littoral Mauritanien. Actes du Colloque, 12-13 Juin 1995, Nouakchott, Mauritanie. CIRAD, Montpellier, France, pp. 93-99.

IUCN (1989). Conservation et Développement dans le Delta Inférieur du Fleuve Sénégal, Mauritanie. International Union for Conservation of $\mathrm{Na}$ ture, Gland, Switzerland.

IUCN (2007). Evaluation de l'Efficacité de la Gestion des Aires Protégées - Tracking Tool: Parc National du Diawling. International Union for Conservation of Nature, Gland, Switzerland.

Kelly, C.M.R.; BARKer, N.P.; Villet, M.H.; Broadley, D.G. \& Branch, B. (2008). The snake family Psammophiidae (Reptilia: Serpentes): phylogenetics and species delimitation in the African sand snakes (Psammophis Boie, 1825) and allied genera. Molecular Phylogenetics and Evolution 47: 1045-1060.

Le Berre, M. (1989). Faune du Sahara. 1. Poissons, Amphibiens et Reptiles. Lechevalier R. Chabaud, Paris, France.

Luja, V.H.; López, J.A.; Cruz-Elizalde, R. \& RAMírez-BAutista, A. (2017). Herpetofauna inside and outside from a natural protected area: the case of Reserva Estatal de la Biósfera Sierra San Juan, Nayarit, Mexico. Nature Con- 
servation 21: 15-38.

Ly, O.K. \& ZeIN, S.A.O.M. (2009). Évaluation Économique d'une Zone Humide: le Cas du Diawling, Mauritanie. International Union for Conservation of Nature, Gland, Switzerland.

Mallon, D.P.; Hoffmann, M. \& McGowan, P.J.K. (2015). An IUCN Situation Analysis of Terrestrial and Freshwater Fauna in West and Central Africa. International Union for Conservation of Nature, Gland, Switzerland.

Nickel, H. (2003). Ökologische Untersuchungen zur Wirbeltierfauna im südöstlichen Mauretanien. Zwei Fallstudien unter Berücksichtigung der Krokodile. Deutsche Gesellschaft für Technische Zusammenarbeit, Eschborn, Germany.

ObSERVATion International (2017). Observation International. Stichting Observation International, Amsterdam, The Netherlands. Available at https://observation.org/. Retrieved on 01 March 2017.

Ohler, A. \& Frétey, T. (2008). Statut du nom Arthroleptis milletihorsini Angel, 1922 (Amphibia, Anura). Alytes 25: 173-175.

PAdial, J.M. (2003). On the presence of Python sebae Gmelin, 1788 (Ophidia: Pythonidae) in Mauritania. The Herpetological Bulletin 84: 30-31.

Padial, J.M. (2006). Commented distributional list of the reptiles of Mauritania (West Africa). Graellsia 62: 159-178.

PN Diawling (2017). Dénombrement International des Oiseaux d'Eau de la Réserve de Biosphère Transfrontalière du Bas Delta du Fleuve Sénégal, Rive Droite (RBT-RIM). Ministère de $l^{\prime}$ Environnement et du Développement Durable, Parc National du Diawling, Nouakchott, Mauritania.

RAMPAO (2015). Réseau Régional d'Aires Marines Protégées en Afrique de l'Ouest. Dakar, Senegal. Available at http:// www.rampao.org/?lang=en. Retrieved on
15 July 2017.

Sánchez-Vialas, A.; Calvo-Revuelta, M. \& Márquez, R. (2017). Ptychadena in Mauritania and the first record of Ptychadena schillukorum. ZooKeys 673: 125-133.

Shine, T.; Robertson, P. \& Lamarche, B. (2001). Mauritania. In L.D.C. Fishpool \& M.I. Evans (eds.) Important Bird Areas in Africa and Associated Islands. Priority Sites for Conservation. Series: BirdLife Conservation Series, vol. 11. Pisces Publications - BirdLife International, Newbury - Cambridge, UK, pp. 567581.

Sow, A.S.; Martínez-Freiría, F.; Crochet, P.A.; Geniez, P.; Ineich, I.; Dieng, H.; Fahd, S. \& BRIto, J.C. (2014a). Atlas of the distribution of reptiles in the Parc National du Banc d'Arguin, Mauritania. Basic and Applied Herpetology 28: 99-111.

Sow, A.S.; Martínez-Freiría, F.; Dieng, H.; FAHD, S. \& BRITO, J.C. (2014b). Biogeographical analysis of the Atlantic Sahara reptiles: environmental correlates of species distribution and vulnerability to climate change. Journal of Arid Environments 109: 65-73.

Trape, J.-F.; Trape, S. \& Chirio, L. (2012). Lézards, Crocodiles et Tortues d'Afrique Occidentale et $d u$ Sahara. IRD Éditions, Marseille, France.

Trape, J.-F. \& MAnÉ, Y. (2006). Guide des Serpents d'Afrique Occidentale. Savane et Désert. IRD Éditions, Bondy, France.

Vale, C.G.; Tarroso, P. \& Brito, J.C. (2014). Predicting species distribution at range margins: testing the effects of study area extent, resolution and threshold selection in the Sahara-Sahel transition zone. Diversity and Distributions 20: 20-33.

Zıмкus, B.M. \& LARson, J.G. (2011). Examination of the molecular relationships of sand frogs (Anura: Pyxicephalidae: Tomopterna) and resurrection of two species from the Horn of Africa. Zootaxa 2933: 27-45. 